\title{
Understanding stages of supply network emergence in technology commercialisation
}

\author{
Tomás Seosamh Harrington* and Jagjit Singh Srai \\ Centre for International Manufacturing, Institute for Manufacturing (IfM), Engineering \\ Department, School of Technology, University of Cambridge, UK \\ *Corresponding author: tsh32@cam.ac.uk
}

\begin{abstract}
This research explores different 'modes' of supply network emergence that may exist in the process of technology commercialisation, and examines how key actors and enterprises design and re-configure their emerging and existing networks. A generic 'stages' model to better understand supply network evolution - in the context of emerging technologies - is developed, based on existing commercialisation case studies, and underpinned by industrial emergence and network theory. The aims of the model are two-fold, namely, to extend theoretical understanding of 'stages' and 'emergence' from a traditional technology and product perspective towards that of supply networks, and to inform existing network analysis approaches (applicable for 'mature' industries) so as to better 'fit' nascent and emerging contexts. Indeed, it is argued that supply networks never quite reach a stage of 'maturity', as organisations continuously look to 're-configure' elements of their legacy networks, leveraging existing capabilities where possible, in response to changes in strategic priorities and the emergence of new market opportunities and threats.

At the practice level, the 'stages' model informs how best to manage critical network resources - supporting the design of alternative business models, and associated supply network strategies, for transforming new technologies into marketable products.
\end{abstract}

Keywords: Supply networks; stages; nascent; emergent; technology commercialisation

Biographical notes: Tomás Seosamh Harrington is a Senior Research Associate whose research interests have included product-service network design, configuring nascent networks for emerging technologies and the mapping and analysis of value creation and capture in complex industrial systems and sub-systems. His current research focus examines how technology 'interventions' are enabling the potential for significant step changes across the pharmaceutical/healthcare value chain from early stage 'system discovery' and clinical trials, through to novel delivery models and the 'enduser'. Specifically, exploring industry transformation through continuous manufacturing and digital factory concepts), and extending the resulting benefits to patients and healthcare providers, through the design of digital supply chains, in a series of commercial and clinical trial contexts. In addition to his research activities, he has been significantly involved in a series of consultancy projects with leading multinational companies, and in the development of management tools for industry. Before joining the IfM's Centre for International Manufacturing in 2009, he worked in industry in a series of senior product design and engineering roles with Intel. He holds Bachelors and PhD degrees in Chemistry and an MBA (with distinction) for which he received a Chartered Management Institute award in 2008.

Jagjit Singh Srai is Head of the Centre for International Manufacturing at the Institute for Manufacturing, University of Cambridge. His main research and practice interests are in the areas of international manufacturing and supply networks, in particular network configuration and industrial 
capability. With over 18 years industrial experience, previous roles have including a series of senior management positions, including that of Manufacturing and Supply Chain Director. A Chartered Engineer and Fellow of the Institute for Chemical Engineers, he holds a Bachelors degree in Chemical Engineering from Aston University and a PhD from the University of Cambridge.

\section{Introduction}

The focus of this research paper is to better understand what role supply networks may play in the successful commercialisation of emerging technologies. Previous academic studies on the strategic roles of supply networks have largely focused on large, well-established, market driven organisations. By definition, these mature networks seek to be highly responsive to well-known requirements of their customers (Jaworski et al., 2000; Sebastio and Golicic, 2008; Srai and Gregory, 2008; Harrington and Srai, 2012). However, having a better understanding of supply network 'emergence', 'evolution', 'transition' and 'reconfiguration' is growing increasingly more critical - due to the dynamic nature of the next generation of industrial enterprises (Harrington et al. 2015).

One critical challenge in the commercialisation of a new technology is that there is no defined pathway to follow. Lack of certainty, in terms of product definition and end-user requirements, forces new, emerging actors and enterprises to experiment with supply network strategies through a process described as 'effectuation' (Sarasvathy, 2001). This process can be very time-consuming; increasing time-to-market, making it difficult to exploit 'first-mover' competitive advantage and reducing opportunities to grow market share.

In better understanding the role supply networks may play in shaping such industrial emergence, the evolution, development and maturity of an industrial system must also be considered e.g. the environment in which one seeks to transform a novel technology successfully into a marketable product. A key consideration here is predicting at which phase of the 'maturity curve' a new product may fit and strategically tailoring to this as required (Simchi-Levi and Fine, 2010). In emerging industries, it is often unclear which product and process architecture will become the 'standard', which compounds the high degree of market uncertainty that already exists (Jaworski et al., 2000; Hills and Sarin, 2003; Simchi-Levi and Fine, 2010).

Many authors in the academic literature suggest that in order to successfully grow a firm to a 'mature' state, various dimensions of the supply network - incorporating resources, partners, suppliers, customers - must all be coordinated (Leibold et al., 2002; Voelpel et al., 2004; Srai and Gregory, 2008; Harrington et al., 2012; Harrington and Srai, 2012). Hence, as well as product and process architecture (and associated business model) considerations, designing the supply network to 'fit' with the relevant maturity stage is critical (Fisher, 1997; Christopher and Towill, 2002; Lee, 2002; Srai and Gregory, 2008; Simchi-Levi and Fine 2010; Harrington and Srai, 2012).

Historically, a popular approach - in the academic literature - has been to consider the industrial 'emergence' process to be composed of several distinct phases or 'stages' - albeit from a variety of different perspectives (e.g. Levitt, 1965; Utterback and Abernathy, 1975; Churchill and Lewis, 1983; Calori, 1985; Kazanjian, 1988; Kazanjian and Drazin, 1989; Kazanjian and Drazin, 1990; Tushman and Rosenkopf, 1992; Moore, 1993; Cooper, 1993; Cooper, 1994; Mankins, 1995; Dodgson, 2000; Rogers, 2003; Ortt and Schoormans, 2004; Suárez, 2004; Hansen and Birkinshaw, 2007; Adomavicius et al. 2007; Phaal et al. 2009; Tao et al . 2010; Den Hartigh et al. 2010). These various 'phases, 'stages' and 'descriptors' - from the many different perspectives listed above - are discussed in more detail in the next section in order to inform model development. In summary, common to most interpretations is the concept of 'process maturity' associated with a product or service. Approaches tend to capture an initial R\&D phase, next the demonstration of a viable technology and then production in large scale. However, it is argued these 'stages' for emerging industries are largely conceptual and descriptive, providing limited content and substance on what the supply network features of evolution may be. This can make identification and classification very 
subjective and does not provide insights on the operational actions that firms need to consider, or those alternative 'options' that may deliver additional supply network benefits. To this effect, this research paper presents a 'stages' model - to better understand 'emergence' in the context of supply networks.

The remainder of the paper is structured as follows: in summary, section 2 reviews the literature on emerging industrial systems and perspectives on 'stages of emergence, and provides a synopsis of key supply network configuration concepts and dimensions. Section 3 describes the approach to developing a conceptual 'stages' model for supply network emergence, by integrating key insights from the literature. The methodology section next summarises the research strategy and process/methods of data collection and analysis. As part of the data analysis technique employed, section 5 presents case narratives, with section 6 summarising cross-case analysis and contribution to theory. Finally, section 7 presents the conclusions and limitations of the study, in addition to directions for future research.

\section{Literature Review}

This section reviews the academic literature and summarises those dimensions of analysis that may be particularly relevant to developing a 'stages' model for supply network emergence. This section is organised in terms of several sub-themes that have emerged from the literature on emerging technologies and industries, and is structured around the following research themes, namely;

- Emerging industrial systems

- Environmental features and network dynamics

- Resources and capabilities

- Alternative business models and strategies

- Supply networks - configuration concepts and dimensions of analysis

- Perspectives on 'stages' of emergence

- Organisational

- Innovation

- Business eco-systems

- $\quad$ Life-cycles and readiness

Key insights, from sections 2.1-2.3 of this review, are then integrated to inform the development of a 'stages' model to better understand 'emergence' - from a supply network perspective in section 3 ..

\subsection{Emerging industrial systems}

Any representation of an industrial system should include the context, resources, activities, processes, actors, and interdependencies that support the creation and delivery of products and services (RAE, 2012). Industrial systems continue to emerge - often enabled by new, innovative manufacturing processes and driven by individual actors, new enterprises, and coalitions of more established firms. Sarasvathy and Dew (2005) consider the commercialisation of a new technology or 'new market creation' as a process involving the coming together of a 'new network of stakeholders'. Hence, a key consideration in analysing emerging industrial systems is the role this new network of key institutional, industrial and supply network actors may play in the development of viable products 
and services (Srai, 2010; Srai et al., 2014). Institutional actors (e.g. government, agencies, universities, innovation hubs, centres of excellence, strategy groups, consultancies) play a central role in the successful development of an industry through influencing the structure, enabling high connectivity between the various industrial system actors, and by providing incentives, subsidies, and publicly-funded research and development projects (Aldrich and Fiol, 1994; Edquist and Johnson, 1997; Jacobsson and Johnson, 2000; Harrington et al., 2016a).

The following sub-sections consider institutional, industrial and supply network actors, in terms of environmental features, network dynamics, resources, capabilities, alternative business models and strategies - in the context of an emerging industrial system.

\subsubsection{Environmental features and network dynamics}

In their study of emergent and mature industries, Nair and Boulton (2008) report that features of 'alternative' environments are seen to develop, with varying levels of dynamism and complexity. In addition, these alternative and highly dynamic environments require organisations to proactively adapt their operations strategy to ensure a fit between competitive priorities and the development of supporting structures (ibid). Traditional approaches to the study of industrial systems have often been developed on the assumption of 'stable' environments, which may not adequately provide theoretical or practical guidance on how to effectively capture new and emerging market opportunities (Zhang et al., 2007; NAE, 2008; Zhang and Gregory, 2011; Harrington and Srai, 2012). Hence, a better understanding of how emerging actors and enterprises may demonstrate 'value' to the rest of the ecosystem will provide insights for network dynamics and effective supply network design (Kirkwood et al, 2009).

Hence, examining and integrating those environmental features, which are influenced by dynamic factors (both internal and external) encompassing market, product, production system, technology, policy, people and culture - from a supply network perspective - is key (Harrington and Srai, 2012). Factors derived from the emerging industry literature also need to be considered here, and includes product and industry life cycles, levels of scientific progress, market and technology innovation, internal efficiencies, rate of imitation by competitors and customer segmentation patterns (Nair and Boulton, 2008; Simchi-Levi and Fine, 2010; Harrington and Srai, 2012).

\subsubsection{Resources and capabilities}

In the context of commercialising technologies, managing resources and capabilities is seen as a critical component through which value may be captured. New actors and enterprises, whilst often recognising the importance of managing internal capabilities (e.g. technologies, processes, information as well as resources), often fail to coordinate the external resource capabilities (e.g. their multi-organisational network of collaborators, suppliers, partners and customers) and core activities they may require (e.g. the scouting of critical component suppliers and targeting of downstream markets and partners). In addition, critical resource and capability requirements (in areas such as operations, finance and strategic marketing) are often overlooked or viewed as being secondary to those required for initial technology development and demonstration (Kirkwood et al., 2009).

Furthermore, previous studies have shown that many enterprises commonly focus on too narrow a segment of the value chain, to an extent that the requirements of the ultimate end-user (as opposed to the immediate customer for the product or technology) are not well recognised (Kirkwood et al, 2009). Hence, knowing the key stakeholders within an emerging industrial system and conversely to be known is critical in order to foster effective cooperation across the entire value chain 
where necessary (Anderson and Tushman, 1990; Hill, 1997; Shapiro and Varian, 1999). In opening up opportunities for the commercialisation of novel technologies, actors may now often partner, in one shape or form for a single commercial opportunity. Large OEMs often look to integrate or partner with university spin-offs or provide joint venture resources to increase their capabilities to (emerging) industry standards. Critically, such practices are likely to increase competitiveness and profitability because key internal activities and business processes may be better managed (Lambert and Cooper, 2000). Hence, new actors and enterprises should look to fully exploit the industrial system in terms of the 'final' end-product and build all necessary competitive resources and capabilities - both internal or external through targeted recruitment, engaging with outside experts, building closer ties with university research centres, and forming strategic alliances that may extend beyond enterprise boundaries in order to integrate key suppliers (Ragatz et al., 1997; Jaworski et al., 2000; Power et al., 2001; Zahra and Nielsen, 2002; Hills and Sarin 2003).

The evolution of complementary products may also have a strong influence on the development of critical resources, assets and capabilities (Helfat, 1997). Complementary product readiness levels can deliver key insights into resolving technological uncertainties (Utterback and Abernathy, 1975; Anderson and Tushman, 1990; Cusumano et al., 1992). Furthermore, managing both applications and complementary products for an emerging technology will have a strong influence on product features as well as those resources made available for its development (Adner and Levinthal, 2002; Adomavicius et al., 2007).

Hence, in the context of this research, it is argued that resources and capabilities may best be approached from three different perspectives: structuring a 'resource portfolio' through (i) defining network roles and responsibilities, (ii) re-grouping resources to build capabilities and (iii) leveraging existing capabilities and products to exploit market opportunities (Lepak et al., 2007; Harrington and Srai, 2012; Harrington and Srai, 2015).

\subsubsection{Alternative business models and strategies}

In the development of a new product or service, enterprises look for effective strategies rather than efficient ones because 'survival' is more critical than optimising 'outcomes' at this early juncture (Churchill and Lewis, 1983; Calori, 1985; Fligstein, 2001). Furthermore, how an enterprise chooses to structure its supply network for a product is critical and should align with the firm's overall strategic direction (Sebastio and Golicic, 2008). Ability to establish a 'dominant design' as an industry standard through licensing, strategically partnering, appropriate positioning strategies, and diversifying when applicable is seen as key here. However, there are benefits, costs, and risks associated with each of these options plus there are additional factors (maturity of competitor capabilities, uniqueness of a product), which may also influence the particular strategy that an enterprise may pursue (Hill, 1997; Utterback and Suárez, 1993).

Two approaches, effectuation and market driving, to establishing an effective supply network around a disruptive technology, have been reported in the literature (Jaworski et al., 2000; Kumar et al., 2000; Hills and Sarin, 2003; Sarasvathy and Dew, 2005; Santos and Eisenhardt, 2009; Holloway and Sebastiao, 2010).

The first approach describes how emerging firms go through stages of effectuation. Given the unpredictable nature of the external environment, an enterprise may pursue the progressive adaptation of a business plan - in stages - in order to match the changing market through a process of trial and error (Thomke 2001; Christensen 2003). This may, ultimately, lead to the emergence of a dominant supply chain strategy even before an enterprise enters a mature stage of development (Sarasvathy and Dew, 2005).

As opposed to matching to changing markets and progressively shaping a network, the second approach focuses on efforts to dominate the shaping of the market rules and norms via a 
market driving strategy (Jaworski et al., 2000). Market driving, or 'demarcating' may be possible if an enterprise is successful in commercialising a disruptive technology or brings about a unique marketing strategy (Kumar et al., 2000). An example of which includes large OEMs who often look to foster early collaboration with smaller emerging enterprises in order to exploit their new skills and capabilities (Kamath and Liker, 1997). By pursuing a market driving strategy, an enterprise may proactively influence the competitive landscape and industry standards, as opposed to be reactive in response to competitor strategies (Jaworski, et al., 2000; Kumar et al. 2002; Hills and Sarin, 2003; Santos and Eisenhardt, 2009).

\subsection{Supply networks}

Sebastio and Golicic (2008) present the case that the successful emergence of a new market, based on a radical technological intervention, depends largely on the parallel development of a new supply network to support commercialisation activities. Harrington and Srai (2012) have previously summarised the key academic literature on supply network configuration concepts from established domains, hence, this section will only provide a synopsis of key points. The study focused specifically on configuration as a 'state', firm archetypes and network context within the broader domain of the configuration literature and considered mature industry network configuration 'options' (Harrington and Srai 2012). Follow up studies, in this area, are looking to develop a methodology for best capturing configuration profiles or 'transitions' associated with technology emergence and disruptive business models.

In addition to the emergence of new networks and enterprises, this research also considers well established organisations looking to capture value and further diversify product portfolios through new technology adoption e.g. new innovative manufacturing processes (such as 'continuous' manufacturing) and the emergence of CMOs, are contributing to the need to reconfigure the pharmaceutical landscape (Srai et al., 2015a,b). To this effect, mature organisations often need to radically 're-configure' their legacy supply networks, leveraging existing capabilities where possible, to support the emergence of a new technology, new operations model or a new business model (Adner and Levinthal, 2002; Adner and Kapoor, 2010). In summary, mature networks (Harrington and Srai, 2012) utilise network structure to capture dispersion in terms of geographical footprint, the dispersion of network units (e.g. shape, levels of vertical and horizontal integration), and interdependence (e.g. levels of partnerships, ownership, flexibility). In the context of emerging industries, the way in which the network is structured may have an impact on which actors capture the most 'value' (Lepak et al., 2007). It has been reported that emerging actors and enterprises seek close partnerships and build their networks around the most influential partners - within an industrial system - who may already have market credibility with a strong and reliable set of customers (Dyer and Singh, 1998; Sarasvathy, 2001; Hills and Sarin, 2003; Sebastio and Golicic, 2008; Harrington and Srai, 2015). Despite understandable concerns over the sharing of IP, resulting in some relationships becoming more prescriptive (Kirkwood et al., 2009), long-term partnerships are proving more popular (as opposed, to say, vertical integration or outsource strategies) within an emerging industry context as they provide better efficiency and flexibility (Blois, 1996; Kay, 1997; Casson, 1998; Womack et al., 1990; Smitka, 1991; Nishiguchi, 1994; Shiba 1997). These partnerships or quasi-partnerships are often characterised by inter-firm relationships that arise from joint investment in capital assets, shared know-how and effective governance mechanisms (Williamson, 1985; Dyer and Singh, 1998; Gulati, 1995a; Gulati, 1995b).

Overall, understanding a target configuration and structure and, in some cases, 'reconfiguring' the appropriate legacy supply network elements is a critical part of this process (Srai and Gregory 2008; Harrington and Srai 2012). An inability to change organisation structure, practices and supply 
network configuration, in line with the evolution of a technology within the industry, can be a major source of failure (Utterback and Suárez, 1993).

\subsection{Perspectives on 'stages' of emergence}

Previous studies have approached stages of 'emergence' or 'maturity' from a variety of different perspectives - examples of which are summarised in table 1.

While research has focused largely on defining industry development, it is often difficult to generalise 'stages' of development as every industry may possess different growth profiles and characteristics; hence, there is often no common ground on which individual case studies can be compared (Greiner, 1972; Churchill and Lewis, 1983; Kazanjian, 1988; Kazanjian and Drazin, 1989; Brown and Eisenhardt, 1995; Churchill, 1997).

Secondly, research in this area has traditionally been product or technology-focused i.e. common features include product focus, technology feasibility, process/industrial improvement, with stage-gate type processes dominating. Although there are some approaches which may relate to 'network' in terms of e.g. organisation and business structure (Kazanjian, 1988; Kazanjian and Drazin, 1989; Kazanjian and Drazin, 1990; Tushman and Rosenkopf, 1992; Den Hartigh et al., 2010), few have considered the role of the supply network and the evolutionary phases through which they must pass as an industry 'transitions' from a state of emergence to a state of maturity.

As discussed briefly in the introduction - in terms of patterns and common development stages - all models examined as part of this study overlap to some extent. A common element is the concept of 'phases' of emergence and maturity descriptors associated with the commercialisation of technologies. The different perspectives presented in the following sub-sections (2.3.1-2.3.4) and organised by sub-theme (organisation, innovation, life-cycles and readiness, and business ecosystems and networks), are then used to inform 'stages' and 'emergence' emergence, from a supply network perspective.

\subsubsection{Organisation}

Utterback and Abernathy's empirical study (1975) looked to link the nature of an innovation and 'stage' of a firm's development (in terms of product, process, strategy and drivers) based on data available from a previous study of successful technological innovations across five different industries. The firms were assigned to a specific stage e.g. stage I characteristics included having an uncoordinated process, a product performance-maximizing strategy and innovations that were market need stimulated. Stage II comprised of having a more segmental process, a sales-maximizing strategy, with most innovations stimulated by technological opportunities. Finally, stage III attributes included a systemic process, a cost-minimizing strategy, with most innovations stimulated by production related factors.

Churchill and Lewis (1983) have proposed a five-stage model for firm development (e.g. Existence; Survival; Success; Take-off; Resource maturity) in relation to small to medium-sized businesses. Each stage may be characterised by size, diversity and complexity and described by five management factors (managerial style, organisational structure, extent of formal systems, major strategic goals, and owner involvement). Churchill and Lewis (1983) argue that knowing which development stage one is in can help prepare and inform firms looking to grow. In summary, the first stage - existence - largely involves the 'customer', through a focus on ensuring order fulfillment and product delivery. A survival stage sees firms enter a critical phase of development where they look to attain a viable business proposition. Next - success - focuses on 'exploitation' and 'expansion', while the fourth phase - take-off - is about sustaining 'growth'. Finally, resource maturity is when a firm may 
look to take the form of a market leader. Furthermore, the paper reports a series of factors that are prominent in determining a firm's success (or failure) These considerations include goals, resources, financials, systems, operational, managerial and strategic capabilities.

From the perspective of firm strategy, Calori (1985) introduces four generic strategies, with one being identified as the most effective for building market share. Focusing on industrial firms' strategies in two emerging (solar-based) industries, he proposes three 'stages of emergence' (e.g. Beginning; Middle; End). In the beginning stage, the dominant characteristic is 'technological uncertainty', where primary firm goals are about (in the order of importance) survival, technological position and market share. The middle stage is characterised by 'firms' entries', where survival and market share take precedence over considerations of technological position. At the end stage, 'shakeout' is the dominant characteristic, where profitability supersedes technological position in terms of goals.

In terms of a growth model for technology-based new ventures (TBNVs), four discrete 'stages' are presented (Kazanjian, 1988; Kazanjian and Drazin, 1989; Kazanjian and Drazin, 1990). Here 'stages' are described as the configuration of organisational design variables representing a firm's response to a set of dominant problems it may encounter over time (Kazanjian 1988) The authors go on to report that 'growth' is partially attributable to the fit between a TBNV's 'stage' and aspects of its structure (Kazanjian and Drazin, 1990). The first stage concerns conception and development where structure and formality are described as being largely non-existent. All activity at this stage is focused on resolving technical issues, formulating business plans, developing prototype products and looking to secure financial backing. The commercialisation stage aims to capture the phase where major focus is on developing the product and/or technology, beyond basic prototyping, towards that of a marketable product. Here, in terms of organisational structure, functional areas begin to emerge but remain largely embryonic, given the limited formal nature of relationships. The third stage - growth centres on the production, sales, and distribution of a marketable product or technology, where an organisation typically is in a state of flux. At this stage, a hierarchical structure often tends to emerge, with centralised decision-making decreasing as an organisation moves to this higher stage. Finally, the stability stage is concerned with market position and the development of next generation products and technologies in order to maintain growth momentum. By this stage, a stable mode of operating has emerged across the organisation, with formal structures, rules and procedures. Interestingly, it was also observed that while role specialisation in e.g. manufacturing and marketing increases by stage, specialisation (in engineering and technology-based roles and functions) is core and remained high across all four stages of growth.

In their paper on organisational determinants of technological change, Tushman and Rosenkopf (1992) argue that technologies evolve through a combination of events, linking organisational complexity with technology change and uncertainty. Here, multiple competing organisations may shape the standards for an emerging industry. Building on the argument that technological change may be characterised by variation, selection and retention (Anderson and Tushman, 1990), the authors propose that a cyclical model with four key components, namely, technological discontinuities (linked to variation - which may be competence enhancing or destroying), eras of ferment (which is characterised by substitution, design competition and technical change), dominant designs (linked to selection) and eras of incremental change (which relate to retention, elaborate dominant design and technological momentum).

Finally in this sub-section, in the context of competing technologies, Suárez (2004) looked to better understand the process by which a technology may achieve dominance. Through a review of the literature across multiple domains, a series of key phase-dependent factors (both firm and environmental) that may affect the emergence of the 'dominant design' are reported. Five key phases are defined as R\&D build up; Technical Feasibility; Market Creation; Decisive Battle; Post-dominance. The $R \& D$ build-up phase explores how a technological field emerges. Here the technology, still unproven, is just coming into existence and the phase may be characterised by the formation and 
restructuring of new and existing linkages respectively. Actors often involve mature entities, with expertise in a complementary technology, coupled with smaller scale operators, which may just consist of a single laboratory in a university research centre (Srai et al, 2014). Next, the technical feasibility phase is often characterised by the emergence of a working prototype demonstrator. Here a firm-level factor - technological superiority - is seen as critical to the final outcome and the 'locking in' of a 'dominant design' (Utterback and Abernathy, 1975; Anderson and Tushman, 1990; Utterback and Suárez, 1993). In terms of environmental factors, this phase may also be influenced by the emergence of an active regulator role. Phase III - Market Creation - is characterised by the arrival of a viable commercial product in the market. Here, market factors (rather than the technology) begin to dominate. In phase IV, a large customer base has typically been formed. Suárez (2004) goes on to describe how a firm-level factor (e.g. this installed base effect) in this decisive battle phase is largely determined by the strength of network effects within the environment. Finally, the post-dominance phase sees a clear dominant technology in the market. Here, having a large installed base is critical in protecting against potential new entrants, particularly in cases where the environment may have strong network effects. Characteristics of this phase include "within-standard" competition, the licensing of production rights, production capabilities and process innovation (Utterback and Abernathy, 1975). This final phase often continues until a technology 'intervention' triggers the emergence of a new dominance design and further product generations (Srai et al, 2014).

\subsubsection{Innovation}

In the area of innovation diffusion theory, Rogers (2003) has characterised five types of 'adopters', namely, innovators, early adopters, early majority, late majority and laggards. It is argued that a population or social network may be broken down into these five types, for any given innovation, with each adopter classification possessing a specified rate of innovation adoption.

In their study on innovation and breakthrough communication technologies, Ortt and Schoormans (2004) introduce the idea of patterns of development linked to phases, which they report as invention; introduction; industrial production (and large-scale diffusion). Common to previous authors in this section (e.g. Churchill and Lewis, 1983; Calori 1985; Saurez, 2004), there are numerous implications for firms, based on the various differences between these phases - hence, the need to adopt different strategies in each individual phase. In a later study on diffusion of product innovations, Ortt and Egyedi (2014) report the importance of timing and start, the effect of pre-existing standards and regulations on subsequent development. Results demonstrated that pre-existing standards and regulations significantly shorten the adaptation phase (e.g. large-scale industrial production and diffusion) of innovations, an effect not found for the development phase (characterised by a first marketable product).

Hansen and Birkinshaw's (2007) approach to evaluating innovation performance - the innovation value chain - proposes three main phases of innovation (idea generation, conversion, and diffusion). The authors explore new roles within an enterprise (the idea of external scouts and internal evangelists), which look to perform critical activities during the different phases (activities summarised here as internal intra-unit and inter-unit idea scoping, external scanning of ideas; selection, funding and promoting internally).

Finally here, in a 'process of innovation' context, Tao et al (2010) introduce the concept of 'Innovation Readiness Levels' (IRL) - depicting the development of an innovation over its lifecycle. By providing better monitoring and control between phases, the IRL approach aims to support the implementation of innovation over the lifecycle more effectively. In summary, six phases involving the lifecycle of innovation are proposed (e.g. Concept; Components; Completion; Chasm; Competition; Closedown) with assessment aspects and criteria identified for each phase. 


\subsubsection{Life-cycles and readiness}

Levitt (1965) introduced the idea of exploiting the product life-cycle concept and the approach is based on four recognisable 'stages' identified for a series of successful products (e.g. Market Development; Market Growth; Market Maturity; Market Decline). The first 'development' stage relates to when a new product is first brought to market. Here, demand (and the technology, at times) has yet to be proven and sales are low. The 'growth' stage then sees an increasing demand as the total market 'expands'. Next, after a period of time, the 'maturity' stage sees demand finally level off until finally (stage 4 - 'decline') a product loses its appeal, which results in a steady drop-off in sales.

From a new product development perspective, Cooper's paper (1994) looked to integrate the results from several historical studies - covering both successful and failed product introductions. Focusing on product readiness (e.g. cycle time reduction) and speed-to-market, the eight key factors derived from the study were product superiority; market orientation; solid up-front homework; product definition; cross-functional team approach; focus and project prioritisation; quality of execution; and a systematic stage-and-gate new product process - summarised here, in terms of stages - as scoping; build business case; development; testing and validation. Linked to product readiness is the idea of Technology Readiness Levels (TRLs), which remains a popular way of assessing both the maturity of a particular technology and in comparing different types of technologies and concepts (Mankins 1995). In summary, nine levels, from basic principles to actual system 'proven' are reported which broadly cover 'basic' research; focused technology development, technology development and demonstration; system development; system 'launch' and operations.

In their preliminary framework for mapping industrial emergence (based on roadmapping principles) Phaal et al (2009) again use a series of historical cases (drawing from twenty applications roadmaps) to link science, technology, application and market-dominated phases (summarised as Precursor; Embryonic; Nurture; Growth; Maturity; Decline/Renewal) and inform strategy and policy application.

Finally, in this sub-section, Theyel et al (2011) introduce the idea of relational 'bridges' and apply the concept to a technology/industry life-cycle framework (Dodgson 2000) as a means of conducting a gap analysis in a study of the solar photovoltaic industry. Stages here consist of Imagining (conceiving an idea); Incubating (setting up a technology demonstration); Scaling (considerations around production and supply chain); Promoting (market positioning focus); Sustaining (establishing the product offering).

\subsubsection{Business ecosystems and networks}

Moore (1993) argues that an organisation cannot be regarded simply as an actor operating within a single industry, but that it makes up a business ecosystem that may transcend multiple sectors. From the business ecosystem viewpoint, a series of enterprises may collectively develop capabilities based on an emerging technology and partner for a single commercial opportunity. This may open up different challenges, within an ecosystem, in terms of cooperation and competition at different stages of development. It is in this context that Moore (1993) proposes four evolutionary stages e.g. birth, expansion, leadership, and self-renewal. During Stage I (birth), entities look to focus on defining market requirements, delivery channels and the value proposition of a new offering. At this stage, individual entrepreneurs, new enterprises, and coalitions of more established firms tend to cooperate by working closely with both customers (if defined) and key suppliers, with the view of gaining firstmover advantage. Stage II (expansion) is characterised by the development of a viable business concept and having the potential to scale up to large-volume production and distribution. It is during this expansion stage that established networks look to eliminate competitive technologies and 
competitors. Cooperation and competition at stage III (leadership) focuses on the need to set out a future vision that key customers and suppliers can buy into, while retaining bargaining power over key stakeholders respectively. Stage IV (self-renewal) may be described as when a mature ecosystem has become sub-optimal - due to changes within the 'industrial system', often driven by institutional and/or industrial trends. Here, environmental features may need to be examined i.e. how they are influenced by internal and external factors such as market or resource conditions that may prompt the need for a restructuring (Moore 1993; Harrington and Srai, 2012).

In their study on understanding technology evolution from an ecosystem perspective, Adomavicius et al (2007) use case examples involving wireless networking (Wi-Fi) technologies and the digital music industry, to test a new conceptual model that highlights both dynamic and interdependent relationships among multiple technologies. Instead of 'in isolation', technology evolution is best viewed as a dynamic ecosystem that needs to include both interrelated and complementary technologies as they collectively interact and impact evolution. Roles that technologies may play within an ecosystem are reported (as components, products and applications, and support and infrastructure), leading to a classification of interaction types (nine in total, based on variations of the technology roles), which the authors describe as paths of influence.

Finally in this section, a key paper informing this supply network emergence research explores the relationship between business networks and technology battles during the technology life cycle. Den Hartigh et al (2010) examine patterns of development, the diffusion of high-tech product categories and how business network structure and composition change during the technology life cycle. In terms of network, the authors examine network size (number of actors), network diversity (diversity of types and actors within the network) and network structure (density or numbers of connections between actors, structural holes, type of structure i.e. core-periphery, amorphous, hubs, chains) and integrate these dimensions with patterns proposed by Ortt and Schoormans (2004) and Suárez (2004) to formulate a framework for testing. Following a comprehensive review of phases reported in the literature section of their study, Den Hartigh et al (2010) propose three, which they describe as innovation (covering the invention to a first market introduction phase), adaptation (from first phase to large-scale industrial production and diffusion) and market stabilisation (covering largescale production to product end-of-life). 


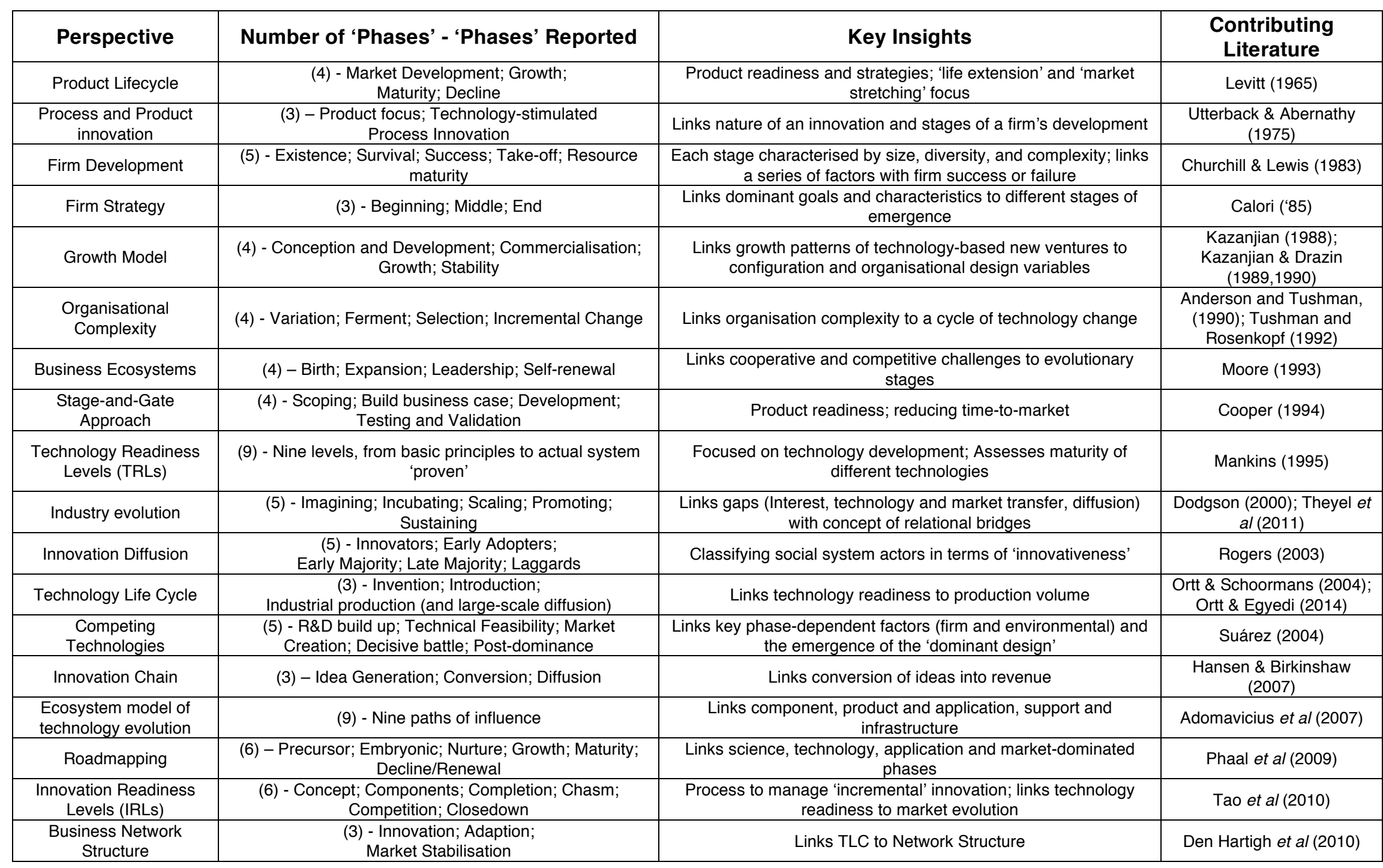




\section{A conceptual stages model for supply network emergence}

In contrast to design 'options' previously presented for mature industries (Zhang et al, 2007; Srai and Gregory, 2008; Harrington and Srai, 2012), a 'stages' model may provide the basis for a more deterministic and valid classification of current and future state supply network development activities. In order to develop a theoretically grounded 'stages' model - from an emerging network perspective, this section integrates key insights from the literature (summarised in section 2) and extends the concept to a supply network context.

The methodological approach to developing a conceptual stages model for supply network emergence is presented in figure 1. First, the key literature across the various research domains (set out in section 2) was integrated here for the purpose of this research. In summary, this investigative phase examined:

- literature on supply networks (configuration concepts, 'states', 'archetypes') supported by in excess of forty network case studies and secondary data from the literature reflecting a number of diverse network forms (data sets capturing engineering, production, supply and service networks) was first used to explore dimensions of analysis as a basis to better understanding the attributes of supply network 'options' and possible 'stages'.

- literature on emerging industry systems and perspectives on 'stages' of emergence, in addition to a series of technology adoption case studies involving technology disruption across three sectors and taking a supply network perspective (Schneemann, 2013; Hadjadj, 2013; Harrington and Srai, 2015b) further informed the dimensions of analysis and provided useful insights to consider in the characterisation and proposed definition of a series of supply network 'stages'.

A 'prototype tool', based on stages of emergence developed from the literature and supporting supply network configuration dimensions, was then used to test the model using a series of case studies involving firms operating within a 'Plastic Electronics' (PE) industrial ecosystem.

$P E$ is a branch of electronics, principally based on polymers rather than silicon, where electronic circuits may be manufactured at relatively low cost and on a 'roll-to-roll' basis by printing electronic inks and materials directly onto a range of flexible substrates (combining traditional printing techniques with emerging technologies).

Outputs from the case study interviews, in combination with case-specific secondary data, were then used in a feedback loop to refine the prototype tool and finalise the stages model of supply network emergence. From the perspective of emerging supply networks, it is proposed that technological and industrial system emergence be best considered in five stages - Embryonic; Fragmented; Formation; Expansion; Stabilisation. These stages are now briefly summarised in subsections 3.1-3.5, with selected key references to support the proposed definitions. 
Figure 1 Literature synthesis: Investigative phase exploring stages of supply network emergence derived from literature and supported by case histories and secondary data

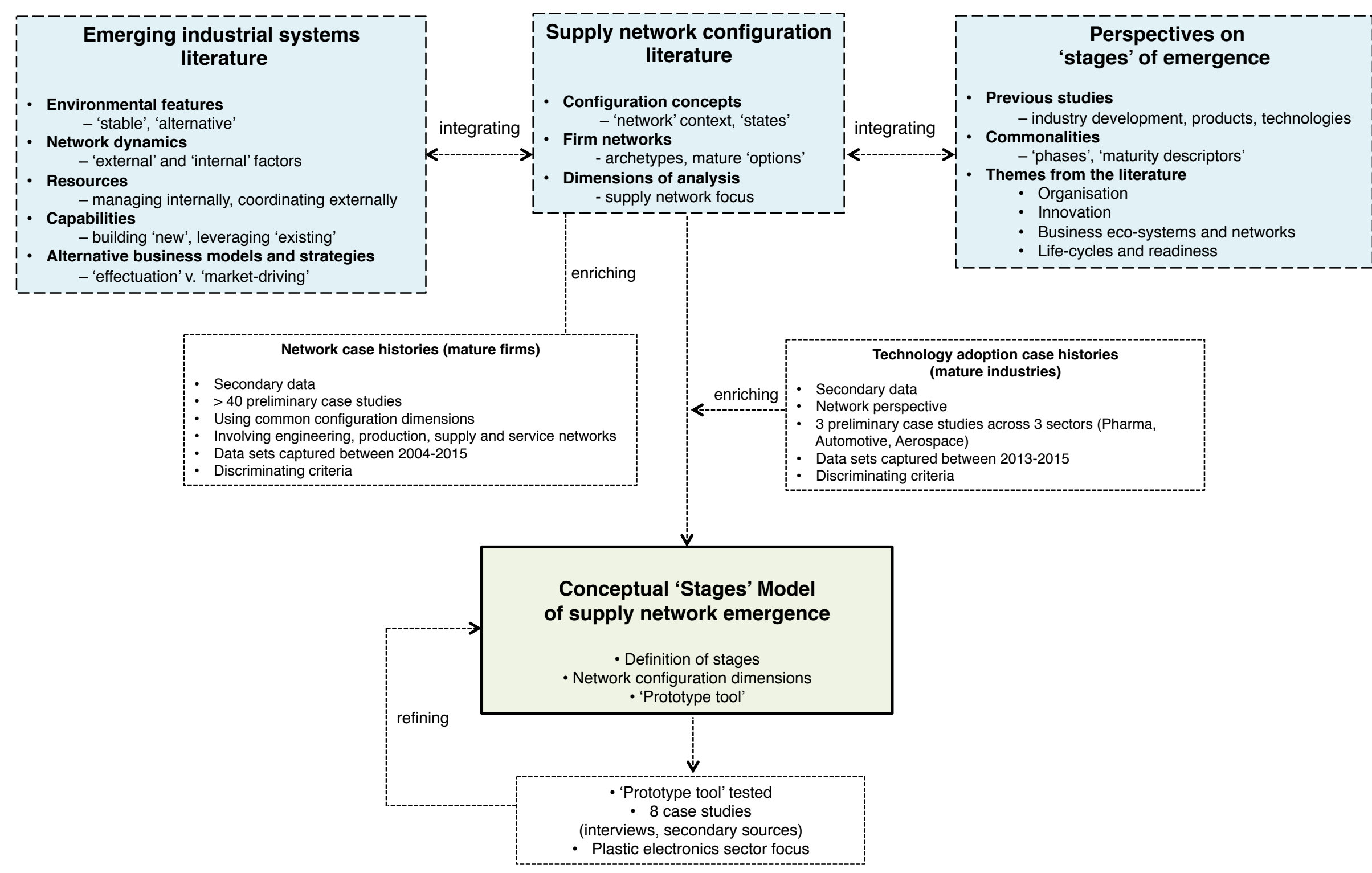




\subsection{Stage I-Embryonic}

The first 'chaotic' or 'embryonic' stage proposed aims to capture supply network activity that is uncoordinated in terms of organisational structure, product definition, formal systems and processes, strategy and drivers (e.g. Utterback and Abernathy,1975; Churchill and Lewis, 1983; Kazanjian and Drazin, 1990; Cooper, 1994; Sarasvathy, 2001; Nair and Boulton, 2008). Factors prominent in determining success (or failure) such as goals, resources, financials, systems, operational, managerial and strategic capabilities (Calori, 1985; Leibold et al., 2002; Voelpel et al., 2004; Ragatz et al., 1997; Helfat, 1997; Jaworski et al., 2000; Power et al 2001; Zahra and Nielsen, 2002; Adner and Levinthal, 2002; Hills and Sarin 2003; Adomavicius et al., 2007; Lepak et al., 2007) are weak or nonexistent. The focus of activities centres on resolving technical issues, formulating value propositions, developing prototypes and securing investment (Utterback and Abernathy, 1975; Anderson and Tushman, 1990; Utterback and Suárez, 1993; Kazanjian and Drazin, 1990). Non-technical resource and capability requirements are often overlooked or viewed as being secondary. Associated supply networks have little or no structure given the lack of or very limited formal nature of relationships (Kazanjian and Drazin, 1990).

\subsection{Stage II - Fragmented}

This stage aims to capture when the major focus is on developing the product and/or technology, beyond basic prototyping, towards that of a marketable product (Kazanjian and Drazin, 1990; SimchiLevi and Fine, 2010; Ortt and Egyedi, 2014; The technology, still often unproven, is just coming into existence and the stage may be characterised by the establishment and realignment of new and existing supply network linkages respectively. With supply networks best described as 'fragmented' here, functional areas begin to emerge in terms of organisational structure, with evidence of increasing 'order' within the network that is often characterised by an emerging commercial strategy and potential for partnering arrangements (Kazanjian and Drazin, 1990; Moore, 1993; Sarasvathy and Dew, 2005; Sebastio and Golicic, 2008).

\subsection{Stage III - Formation}

This middle stage marks the 'formation' of supply networks and the 'emergence' of an 'industry', and may be characterised by 'firm entry', where survival and market share start to take precedence over considerations of technological position (Churchill and Lewis, 1983; Calori, 1985; Fligstein, 2001). Focus may centre on defining market requirements and delivery channels for a new offering (Moore, 1993; Kamath and Liker, 1997; Jaworski et al., 2000; Kumar et al., 2000; Thomke 2001; Christensen 2003; Sarasvathy and Dew, 2005; Den Hartigh et al., 2010). It broadly covers the transition from viable pilot production of a new technology or delivery platform to a completed value chain with an end-user in the form of an early adopter. At this stage, individual entrepreneurs, new enterprises, and coalitions of more established firms tend to cooperate by working closely with both customers (if defined) and key suppliers, with the view of gaining first-mover advantage. Characteristics of trust building and definition of selection processes are critical, in terms of the supply network here, as enterprises seek close partnerships and look to build their networks around the most influential partners who may already have market credibility with a strong set of customers (Dyer and Singh, 1998; Sarasvathy 2001; Hills and Sarin, 2003; Suárez, 2004; Sebastio and Golicic, 2008; Harrington and Srai, 2015). 


\subsection{Stage IV - Expansion}

Characterised by the development of a viable business concept and having potential for scale-up, it is at this 'expansion' stage that multiple customers begin to develop and competitive technologies emerge (Churchill and Lewis, 1983; Moore, 1993; Srai, 2010; Srai et al., 2014). A hierarchical structure often tends to emerge as organisations move to this higher stage, with focus on production, sales, and distribution of a marketable product or technology (Utterback and Abernathy 1975; Kazanjian, 1988; Kazanjian and Drazin, 1989; Kazanjian and Drazin, 1990). The organisation typically is in a state of flux as it looks to eliminate competitive technologies and competitors. In response, supply network elements often undergo rapid and continual change as the associated value chain evolves (Anderson and Tushman, 1990; Hill, 1997; Shapiro and Varian, 1999; Hansen and Birkinshaw, 2007).

\subsection{Stage $V$ - Stabilisation}

With levels of resource maturity in evidence (Churchill and Lewis, 1983), focal firms may look to take the form of a market leader in this 'stabilisation' stage (Den Hartigh et al., 2010). Clusters of network actors start to form, as collaborative models begin to gain traction over competitive technologically differentiated approaches (Kamath and Liker, 1997). Most innovations may now be driven by production-related factors (Utterback and Abernathy 1975). Here, the associated supply network may start to cohere into the form it will take for a mature and viable industrial system (Srai et al., 2014).

\section{Methodology}

The following sections present an overview of the methodological approach used in his research paper. Section 4.1. briefly clarifies our research philosophy and discusses the choice of research strategy and alternative designs considered. Section 4.2. provides both details on the data collection process and methods, including information regarding the qualitative investigation and case studies development (interviews and timescales) and summarises the data analysis techniques employed to inform the development of the stages model.

\subsection{Research strategy}

A research strategy aims to provide overall direction to a study including the process by which the research is conducted (Remenyi et al., 2003). Upfront clarification of the research philosophy plays an integral part in this, as it informs the underlying philosophical assumptions that may support final conclusions. In building a logical research design, our research philosophy follows interpretive rather than positivistic logic because of the exploratory nature of the study in question and the objective to develop an understanding of a new and contemporary phenomenon.

The goals of the researcher and the very nature of the research topic also influence the selection of this strategy (Benbasa, 1984). In deriving a conceptual stages model, alternative research designs were first considered based on criteria set out by Yin (2009). The alternative design options (i.e. experiment, survey, archival analysis and case study) leading to a final decision on research strategy were based on (a) the type of research question (b) extent of control over actual behavioural events and (c) the degree of focus on contemporary events (ibid).

The multiple-case study strategy we adopt is in line with Yin's definition of it being an empirical inquiry that investigates a contemporary phenomenon both in-depth and within its real-life 
context. The approach is particularly appropriate here as this study seeks to explore both practicebased (where the insights of key industrial stakeholders are critical) and emerging phenomena when research and theory is at an exploratory or formative stage (Eisenhardt, 1989; Meredith, 1998; Eisenhardt and Graebner, 2007; Yin, 2009).

\subsection{Data collection and analysis - process and methods}

In addition to the emergence of new networks and enterprises, this research also considers well-established organisations looking to capture value and further diversify product portfolios through new technology adoption. The PE sector was specifically targeted; it is argued that it is a prime example of an 'emerging industry' - where there is a mix of established actors and new entrants, and is combining traditional printing techniques with novel technologies.

As part of the data collection process, potential case study organisations were first identified from an industrial ecosystem map of the PE sector in which key institutional, industry sector specialists and supply network actors had been captured (Baril et al, 2012), using an approach previously reported (Srai 2010; Srai et al., 2014). In order to properly test the conceptual stages model, the following criteria were set out to ensure a balance of (i) new emerging enterprises with innovative manufacturing processes and (ii) more established firms who were looking to leverage existing capabilities, processes and techniques developed in the wider 'electronics' industry. In summation, case studies should;

- represent a diversity of enterprises operating at different (and multiple) points within the value chain

- represent enterprises operating at varying 'stages' of development

- represent supply networks which were either created organically or involved some form of radical transformation of existing networks and

- exhibit alternative evolution paths, hence, providing a broader understanding of the key characteristics of emerging supply network 'stages'.

Using this pre-screening step, and on the basis of general practical considerations involving availability of interviewees and accessibility to sensitive information, eight case studies were selected based on their ability to allow full exploration and test of the conceptual model introduced in section 3 . Descriptors of the case study selections are summarised in table 2 and are organised by cluster (i.e. materials developer, component developers and product assemblers) in order to capture potential synergies across networks operating at similar points, and at various stages of development, within the value chain

In order to ensure a coherent and industry-wide representation of the sector, the data collection process involved secondary as well as primary data, and included annual reports of the selected cases, news articles, press releases, market reports for the sector, websites and company presentation material. This integrative use of secondary and primary evidence formed the basis of a data triangulation process, which checked evidence across multiple sources of data in order to increase validity and reliability (Eisenhardt 1989; Yin 2009).

The data collection method involving gathering primary data sources through eight semistructured interviews conducted with the case companies between March 2010 and January 2011. All interviewees were CEOs, managers or senior engineers who were still active within each case organisation and, hence, knowledgeable about organisational and technology timelines, supply network development history and overall firm strategy. The interviews lasted approximately two hours and consisted of two parts; first, respondents were asked to provide a general overview of their 
specific company, product concept, technology development process, supply network structure (including partnerships), their view on overall industry dynamics and opportunities for the sector. Next, interviewees mapped out the development of their supply network, capturing various potential evolution paths (i.e. previous, current, future, alternative scenarios) for selected nodes of their respective networks using the supply network emergence stages model, supported by network configuration dimensions derived from the academic literature. In order to better understand 'transitions', with respect to dimensions and stages as defined by the conceptual model, these evolution paths from current to 'desired' options were discussed in detail. Definitions and descriptors of the 'stages' of supply network emergence model were also discussed and then refined, based on valuable insights from the case study respondents. Finally, repeat access via either informal follow-up meetings or by e-mail correspondence was agreed in order to validate data and seek clarification where required.

Table 2 Case study descriptors

\begin{tabular}{|c|c|c|c|c|c|c|c|c|}
\hline $\begin{array}{c}\text { Case } \\
\text { Study }\end{array}$ & $\mathbf{1}$ & $\mathbf{2}$ & $\mathbf{3}$ & $\mathbf{4}$ & $\mathbf{5}$ & $\mathbf{6}$ & $\mathbf{7}$ \\
\hline $\begin{array}{c}\text { Company } \\
\text { descriptor }\end{array}$ & $\begin{array}{c}\text { Materials } \\
\text { Developer }\end{array}$ & $\begin{array}{c}\text { Component } \\
\text { Manufacturer }\end{array}$ & $\begin{array}{c}\text { Component } \\
\text { Manufacturer }\end{array}$ & $\begin{array}{c}\text { Component } \\
\text { Manufacturer }\end{array}$ & $\begin{array}{c}\text { Product } \\
\text { Assembler }\end{array}$ & $\begin{array}{c}\text { Product } \\
\text { Assembler }\end{array}$ & $\begin{array}{c}\text { Product } \\
\text { Assembler }\end{array}$ & $\begin{array}{c}\text { Product } \\
\text { Assembler }\end{array}$ \\
\hline $\begin{array}{c}\text { Company } \\
\text { Type }\end{array}$ & OEM & SME & OEM & OEM & SME & OEM & OEM & OEM \\
\hline Footprint & Global & Regional (UK) & $\begin{array}{c}\text { Regional } \\
\text { (Asia) }\end{array}$ & Global & $\begin{array}{c}\text { Regional } \\
\text { (UK) }\end{array}$ & Global & Global & $\begin{array}{c}\text { Regional } \\
\text { (UK) }\end{array}$ \\
\hline Network focus & Upstream & Upstream & $\begin{array}{c}\text { Upstream- } \\
\text { downstream }\end{array}$ & Upstream & $\begin{array}{c}\text { Downstrea } \\
\mathrm{m}\end{array}$ & $\begin{array}{c}\text { Downstrea } \\
\mathrm{m}\end{array}$ & Downstream & $\begin{array}{c}\text { Downstrea } \\
\mathrm{m}\end{array}$ \\
\hline $\begin{array}{c}\text { Respondent } \\
\text { profile }\end{array}$ & $\begin{array}{c}\text { Chief } \\
\text { Innovation } \\
\text { Officer }\end{array}$ & $\begin{array}{c}\text { Chief } \\
\text { Executive } \\
\text { Officer/Senior } \\
\text { Engineer }\end{array}$ & $\begin{array}{c}\text { Chief } \\
\text { Executive } \\
\text { Officer }\end{array}$ & $\begin{array}{c}\text { Head of } \\
\text { Division for } \\
\text { Sensor } \\
\text { Technology }\end{array}$ & $\begin{array}{c}\text { Senior } \\
\text { Engineer }\end{array}$ & $\begin{array}{c}\text { Sales and } \\
\text { strategic } \\
\text { planner }\end{array}$ & $\begin{array}{c}\text { Principle } \\
\text { engineer for } \\
\text { advanced } \\
\text { technologies }\end{array}$ & $\begin{array}{c}\text { Chief } \\
\text { Executive } \\
\text { Officer }\end{array}$ \\
\hline
\end{tabular}

\section{Case study narratives}

The data analysis technique employed as part of this study analysed each cluster (i.e. materials developer, component developer and product assembler), before conducting a cross-case analysis (see section 6) in order to capture stages of supply network emergence for the overall PE sector. Short descriptions and analysis of each of the case companies in each cluster, based on an integration of primary data and secondary sources, are also presented here and focus on aspects of manufacturing capability, supply network configuration and stage of emergence.

\section{Case 1. Materials developer}

Case organisation 1 is a global company with production facilities in the US, Asia, and Europe and ia a world leader for film products for use in food packaging, photo systems, electrical products and electronics. It has a very well defined business model as plastics (the core business) is already a mature industry, based on commodity materials. The organisation has expanded its product portfolio by supplying films for $\mathrm{PE}$, and is working towards creating plastic substrates as an alternative to glass with cost efficient and high volumes processes. Hence, characteristics of its PE supply network include having a mature network shape with strong supplier connectivity. However, levels of commercial control and customer partnership are significantly less developed. However, the firm is working very closely, through joint development programs with product manufacturers, to be responsive when markets emerge. With its specialismin film production, the case organisation is in an excellent position to aid SMEs develop both materials and manufacturing equipment that is 
compatible with their films, and is currently working very closely with clients at early stages of development in order to meet the required product specifications. At the same time, the firm is able to engage with larger players due to its legacy manufacturing capabilities. Production capabilities, with respect to PE films are considered to be in the 'stabilisation' phase of development with capacities exceeding market requirements.

\section{Cases 2-4. Component Manufacturers}

The specialised capability of case organisation 2 lies in ultra-thin and low-cost flexible microcircuits that may be incorporated into mass-market objects and packaging. While this small-to-medium sized enterprise (SME) has a very well developed regional customer base in the UK, it is becoming increasingly affected by global customer pull, with no mature network structure to support this opportunity.

As OEMs, case organisations 3 and 4 have similar supply network profiles to each other. Case organisation 3 is a global player in the research, design and manufacture of electronic components with clients including Apple, Bosch, HP and Nokia. While already well established in the electronics market with a strong supplier network, the industry environment for PE is quite diverse (developing integrated microsystems for medical devices) compared to its core offerings. Case organisation 4 is a high-tech device manufacturer that develops electronic components and batteries, primarily focusing on display, energy, and communication applications. Its network remains regional and its biggest customers include LG and Samsung. In the context of PE, while network structure is weak, both have demonstrated growing interdependent links with the key industrial actors. However, there is a clear difference in the types of relationships they are developing in this space. Case organisation 3 has focused on developing supplier partnerships, with case organisation 4 extensively developing its customers, in order to to sustain its development. Both firms are considering a consolidation of their networks through acquiring competitors and suppliers upstream.

\section{Cases 5-8. Product Assemblers}

Two product assembly companies, with regional (UK) footprints, demonstrate many of the early mature characteristics in terms of network structure. Case organisation 5, a developer and manufacturer of lightweight solar modules based on printed plastic, was only established in 2010. Despite its infancy, the firm benefits from its high-speed manufacturing capability and low fabrication costs, and has seen its network dispersion grow from a single location to have a global reach in less than twelve months. In addition to increased dispersion, the strength of its partnerships has also increased and stabilised. Case organisation 8 develops and manufactures flexible plastic displays, based on a licensed transistor technology, and has a strong network structure around individual site centres, customised engineering systems and supplier partnerships which are largely transactional. Engineering resources meet industry requirements and the product features have already been defined. However, commercial and engineering control are still at an early stage of development as the firm is undergoing a transition, from being venture capital-funded to finding a route to market, in commercialising its technology.

Case organisations 6 and 7 exhibit a very developed network infrastructure due to their leading positions within the wider electronics industry and in the area of LCD displays, in particular. Both companies are leveraging this network infrastructure and industry presence to develop their PE business segments, through engaging in joint ventures and actively cooperating with technology innovators in order to develop their know-how. Both case organisations support their suppliers to ensure they have the resources to develop innovative technologies and in the required quantities. 
Furthermore, they are also exploring a vertical integration strategy downstream by acquiring competitors and suppliers of materials for display modules. As well as bringing stability within an emerging sector (where the number of suppliers is very limited) vertical integration of material suppliers may ensure efficient resource management and reduce times-to-market.

\section{Cross-case analysis and theoretical contribution}

$\mathrm{PE}$ is a leading example of a new emerging industry, with novel products being manufactured using a hybrid of traditional printing techniques with emerging technologies. This is also reflected in the composition of the actors within the sector. It is comprised of new entrants driving innovative manufacturing processes, coupled with more established firms looking to diversify their product portfolios. In terms of supply networks, there is often a wide disparity here. Small emerging firms focus their activities on resolving technical issues, developing prototypes and securing investment while 'non-technical' requirements (such as supply network design) are often overlooked. On the other hand, the larger players look to leverage existing capabilities, processes and techniques developed in the wider 'electronics' industry. The case studies selected as part of this study were used to capture the composition of 'current' PE sector supply networks. This involved a diversity of firms at different 'stages' of development and represented supply networks which were either created organically (or are still in the process of) and involved some form of radical transformation of existing networks. For reasons of confidentiality, analysis of individual cases is anonymised, however, an overall snapshot of the PE sector is a valuable contribution. Figure 2 combines the final stages model of supply network emergence in five stages (e.g. Embryonic; Fragmented; Formation; Expansion; Stabilisation) with an overview of where the eight PE case study supply networks are positioned (across the x-axis) versus each configuration dimension on the $y$-axis. Collectively, the sector exhibits alternative evolution paths, hence, providing the study with a broader understanding of the key characteristics of emerging supply network 'stages'. 


\section{Stage of supply network emergence}

\begin{tabular}{|c|c|c|c|c|c|c|c|}
\hline & & \multirow[b]{2}{*}{$\begin{array}{l}\text { Levering legacy } \\
\text { network 'options }\end{array}$} \\
\hline & & 'Embryonic' & 'Fragmented' & 'Formation' & 'Expansion' & 'Stabilisation' & \\
\hline \multicolumn{2}{|c|}{$\begin{array}{l}\text { Network configuration - } \\
\text { dimensions of analysis }\end{array}$} & $\begin{array}{l}\text { 'Chaotic' stage with } \\
\text { little or no supply } \\
\text { network structure. } \\
\text { Weak or non-existent } \\
\text { product definition }\end{array}$ & $\begin{array}{l}\text { Supply network } \\
\text { 'fragmentation' and } \\
\text { increasing order'.' } \\
\text { Emerging commercial } \\
\text { strategies with } \\
\text { potential for } \\
\text { partnering } \\
\text { arrangements }\end{array}$ & $\begin{array}{c}\text { Supply network } \\
\text { 'creation' with } \\
\text { transition from viable } \\
\text { pilot to a complete } \\
\text { value chain, with an } \\
\text { early adopter. } \\
\text { Characteristics } \\
\text { include trust building } \\
\text { and the selection of } \\
\text { various processes }\end{array}$ & $\begin{array}{c}\text { Supply network } \\
\text { undergoes rapid and } \\
\text { continual change as } \\
\text { the value chain } \\
\text { evolves. Multiple } \\
\text { customers and } \\
\text { competitive } \\
\text { technologies begin to } \\
\text { emerge }\end{array}$ & $\begin{array}{l}\text { Supply network starts } \\
\text { to cohere into the form } \\
\text { it will take for a } \\
\text { mature, viable } \\
\text { industrial system. } \\
\text { Clusters of network } \\
\text { actors start to form, } \\
\text { collaborative models } \\
\text { begin to gain traction }\end{array}$ & $\begin{array}{c}\text { Established firms } \\
\text { reconfigure their } \\
\text { existing supply } \\
\text { networks - leveraging } \\
\text { existing capabilities, } \\
\text { processes and } \\
\text { techniques developed }\end{array}$ \\
\hline \multirow{2}{*}{$\begin{array}{l}\text { Network } \\
\text { Structure }\end{array}$} & Dispersion & 0 & & & & & \\
\hline & Interdependence & & & & & & \\
\hline $\begin{array}{c}\text { Network } \\
\text { Dynamics }\end{array}$ & Standardisation & & C & & & & \\
\hline \multirow{2}{*}{$\begin{array}{c}\text { Governance } \\
\text { and } \\
\text { Coordination }\end{array}$} & $\begin{array}{l}\text { Commercial } \\
\text { Control }\end{array}$ & 0 & & O & & & \\
\hline & $\begin{array}{c}\text { Engineering } \\
\text { Control }\end{array}$ & & & & & & \\
\hline \multirow{3}{*}{$\begin{array}{c}\text { Support } \\
\text { Infrastructure }\end{array}$} & $\begin{array}{l}\text { Engineering } \\
\text { Systems }\end{array}$ & $\bigcirc \bigcirc$ & & O & & & \\
\hline & $\begin{array}{l}\text { Engineering } \\
\text { Resources }\end{array}$ & & & & & & \\
\hline & Culture & 0 & & $\bigcirc \bigcirc \bigcirc \bigcirc$ & & & \\
\hline \multirow{2}{*}{ Relationships } & $\begin{array}{l}\text { Partnership- } \\
\text { supplier }\end{array}$ & 0 & & & & & \\
\hline & $\begin{array}{l}\text { Partnership- } \\
\text { customer }\end{array}$ & & 0 & & & & \\
\hline Product & Configuration & & 00 & & & 0 & \\
\hline
\end{tabular}


In terms of network structure, two product assemblers demonstrate many mature network characteristics (leveraging existing connections). In terms of dispersion (6/8 cases) and

interdependence (7/8 cases), the majority of cases see their existing supply networks as spanning the five stages (e.g. Embryonic; Fragmented; Formation; Expansion; Stabilisation) as would be expected given the diversity of firms at different stages of development. .

On examining network dynamics and standardisation, half of the case study networks are in the 'expansion' stage, where focus centres on the production, sales, and distribution of a marketable product or technology. For one case study firm, established in 2010, its network dispersion has grown rapidly from a single location to having global dispersion (enabled by the strength of its network partnerships), advancing to a 'stabilisation' stage in less than a year.

With respect to governance and coordination and support infrastructure, the majority of respondents identified their networks as being at the 'formation' stage - here, engineering and commercial control, systems and resources may be characterised by the organisations working closely with both customers (in specific cases) and key suppliers, with trust building being vital in terms of supply network development. Interestingly, while one case study firm regarded engineering resources to be well advanced and had a well-defined end product, governance and coordination (in terms of engineering and commercial control) remained at the 'formation' stage and had become an area of focus.

With PE predominantly an emerging industry, a good proportion of supply networks are currently positioned within 'formation, 'expansion' and 'stabilisation' stages, with respect to configuration dimensions. However, the OEMs possess mature and well-defined networks, and this is reflected in terms of relationships, with $50 \%$ of the case studies leveraging their existing links with high levels of supplier and customer connectivity in evidence. However, this strong supplier connectivity is in contrast with the level of commercial control, which remains significantly less developed. Here, firms are partnering very closely, often through joint development programs with product manufacturers, to be responsive when a market emerges as well as with customers at early stages of development in order to meet all the product specifications. For two of the larger multinational OEMs, who are market leaders in their core sector, the most significant supply network consideration - in a PE context - are supplier partnerships, which are identified being as 'fragmented'. While the strength of their networks lie with established customer partnerships and engineering capabilities, the sourcing of new materials and developing stronger relationships through joint venture agreements or exclusive contracts with smaller technology innovators is a priority.

Finally here, in terms of product, two of the smaller case study firms have developed novel technology to be integrated in innovative products (e.g. such as flexible e-readers and solar cells). This requires the sourcing of new suppliers and new markets to be developed. Hence, supply networks may be best described as 'fragmented' and need to be created around the disruptive technology.

In terms of theoretical contribution, current perspectives on early stage supply network development in new and emerging industries are largely descriptive, and provide limited detail on configuration elements and options. Previous studies on the strategic roles of supply networks have largely focused on large, well-established, market driven organisations, their established products and their extended networks. In contrast, emerging networks often have limited or no structures supporting products with a weak initial focus and definition. The prototype tool developed as part of this study integrates the network configuration approach with a conceptual stages model of supply network emergence, derived from the literature, in order to examine emerging supply network development and evolution using a series of case studies. Outputs inform network theory and extend existing network configuration concepts, recently applied in more mature industries (e.g. Shi and Gregory, 
1998; Zhang et al, 2007; Srai and Gregory, 2008; Harrington and Srai, 2012), to better 'fit' emerging contexts. Table 3 highlights the contribution of this study to operations management research in the area of network configuration.

Comparing configuration concepts in mature supply networks (Srai and Gregory, 2008) and emerging contexts (this study), structure in a mature context is focused on tier structure and shape, addressing increasing geographical dispersion and integrating mechanisms. In an emerging context, there are different considerations for the network designer which may include the set-up of new partnering arrangements within emerging clusters of activity at a new location, while leveraging critical elements of pre-existing supply networks that may be well established and relevant to an emerging context.

With respect to network dynamics, a mature network configuration focuses on the flow of materials and information between and within key unit operations, replenishment modes, and (well understood) supply-demand dynamics. In an emerging supply network context, it is more about leveraging existing and establishing new capabilities, with emerging firms often functioning using an 'old and new' hybrid model of customised and established processes. Before industry-standard processes have been developed, firms often have to first demonstrate their 'value' to the overall network. Knowing the key stakeholders within an emerging industrial system and conversely to be known is critical in order to foster effective cooperation when required.

In terms of governance and coordination, key network partners and associated inter-firm governance mechanisms are prioritised in a mature supply network setting (likewise in maintaining key inter-firm relationships with partners, in a mature context). For emerging networks, balancing commercial and engineering control is now an area of focus. Partner and process selection (customers and suppliers) and developing longer-term relationships (new and existing) are critical in an emerging context. When opportunities for the commercialisation of novel technologies arise, actors may often partner for a single commercial opportunity. This may open up different challenges for supporting infrastructure of an emerging network at different stages of development in terms of cooperation (e.g. allocation of critical resources and building of trust) and potential for competition (e.g. concerns over IP) with multiple partners.

Finally in terms of product, mature networks focus on modularity, SKU portfolios and profiles while in the case of emergent, focus is somewhat blurred given a lack of certainty, in terms of product definition and end-user requirements. In an ideal case, a rapid consolidation of concepts would lead to the lock-in of a defined product.

The stages model also extends theoretical understanding of 'stages' and 'emergence', from a traditional technology and product perspective, towards that of supply networks. Although some research may have spoken of 'network', in terms of organisation and business structure, few have considered the role of the supply network and the stages through which an industry may 'transition' from emergence to a mature industrial system. While the configuration dimensions, presented in table 3 , have been used to represent established mature networks with multiple archetypal forms, it could be argued that some of these dimensions may not be applicable in an emerging network context. Hence, there is a requirement to validate which network configuration dimensions and subdimensions remain relevant in emerging industry contexts and to refine accordingly in order to best capture configuration profiles associated with technology emergence and disruptive business models. In theory, this validation could be used as a basis to further extend network configuration concepts to capture 'transitions' between both emerging and mature stages. This may only be achievable with a sufficient level of granularity and discrimination, through the use of multiple cross-sector case studies involving industries at different levels of maturity. 
Table 3 Network configuration dimensions - applied in an emerging supply network context

\begin{tabular}{|c|c|c|c|c|c|c|}
\hline & \multicolumn{6}{|c|}{ Operations Management Research on Network Configuration } \\
\hline & Domain & $\begin{array}{l}\text { Production } \\
\text { Networks }\end{array}$ & $\begin{array}{l}\text { Engineering } \\
\text { Networks }\end{array}$ & Supply Networks & $\begin{array}{l}\text { Service Supply } \\
\text { Networks }\end{array}$ & $\begin{array}{l}\text { Emerging Supply } \\
\text { Networks }\end{array}$ \\
\hline & $\begin{array}{l}\text { Supporting } \\
\text { Literature }\end{array}$ & $\begin{array}{c}\text { (Shi and Gregory, } \\
1998)\end{array}$ & (Zhang et al, 2007) & $\begin{array}{c}\text { (Srai and Gregory } \\
\text { 2008) }\end{array}$ & $\begin{array}{c}\text { (Srai, 2011; } \\
\text { Harrington et al, } \\
\text { 2012; Harrington and } \\
\text { Srai, 2012; Harrington } \\
\text { and Srai, 2016b) }\end{array}$ & This study \\
\hline & $\begin{array}{l}\text { Summary of } \\
\text { cases }\end{array}$ & $\begin{array}{l}\text { Ten cases in } \\
\text { aerospace, } \\
\text { electronics, heavy } \\
\text { engineering and } \\
\text { pharmaceuticals }\end{array}$ & $\begin{array}{c}\text { Seven in-depth cases } \\
\text { in aerospace, } \\
\text { automobile, electrics } \\
\text { and electronics and } \\
\text { FMCG sectors }\end{array}$ & $\begin{array}{c}\text { Ten exploratory and } \\
\text { ten in-depth cases in } \\
\text { aerospace, } \\
\text { electronics, FMCG, } \\
\text { garments and } \\
\text { pharmaceuticals }\end{array}$ & $\begin{array}{c}\text { Four case studies } \\
\text { involving complex } \\
\text { 'product-service } \\
\text { solutions' in } \\
\text { aerospace, naval, } \\
\text { power and telecoms }\end{array}$ & $\begin{array}{l}\text { Eight case studies in } \\
\text { the plastic electronics } \\
\text { sector }\end{array}$ \\
\hline \multirow{6}{*}{ 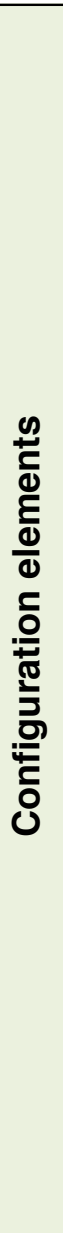 } & Structure & $\begin{array}{c}\text { Plant role } \\
\text { characteristics; } \\
\text { geographic } \\
\text { dispersion; network } \\
\text { evolution }\end{array}$ & $\begin{array}{c}\text { Geographic } \\
\text { dispersion; resources } \\
\text { and roles of } \\
\text { engineering centres; } \\
\text { rationales for network } \\
\text { structure design }\end{array}$ & \begin{tabular}{|c|} 
Supply network tier \\
structure and shape; \\
geographical \\
dispersion; supply \\
network mapping; \\
integrating \\
mechanisms
\end{tabular} & $\begin{array}{l}\text { Multi-organisational } \\
\text { network structure; } \\
\text { service archetypes }\end{array}$ & $\begin{array}{l}\text { Leveraging existing } \\
\text { locations and } \\
\text { linkages; Initial } \\
\text { partnering } \\
\text { arrangements; } \\
\text { Emerging clusters }\end{array}$ \\
\hline & $\begin{array}{l}\text { Network } \\
\text { Dynamics }\end{array}$ & $\begin{array}{l}\text { Response } \\
\text { mechanisms }\end{array}$ & $\begin{array}{c}\text { Operational } \\
\text { processes supporting } \\
\text { engineering } \\
\text { information flows }\end{array}$ & $\begin{array}{c}\text { Flow of materials and } \\
\text { information between } \\
\text { and within key unit } \\
\text { operations; } \\
\text { replenishment mode } \\
\text { and supply-demand } \\
\text { dynamics }\end{array}$ & $\begin{array}{l}\text { Service supply } \\
\text { contracting mode; } \\
\text { through-life } \\
\text { perspectives }\end{array}$ & $\begin{array}{l}\text { Hybrid of customised } \\
\text { and established } \\
\text { processes; Actors } \\
\text { demonstrating their } \\
\text { 'value' to the network }\end{array}$ \\
\hline & $\begin{array}{c}\text { Governance and } \\
\text { Coordination }\end{array}$ & $\begin{array}{c}\text { Horizontal and } \\
\text { vertical coordination }\end{array}$ & $\begin{array}{c}\text { Governance, } \\
\text { including authority } \\
\text { structure and } \\
\text { performance } \\
\text { measures }\end{array}$ & $\begin{array}{c}\text { The role of key } \\
\text { network partners and } \\
\text { inter-firm governance } \\
\text { mechanisms }\end{array}$ & $\begin{array}{l}\text { Service network } \\
\text { governance modes }\end{array}$ & $\begin{array}{l}\text { Balancing commercial } \\
\text { and engineering } \\
\text { control }\end{array}$ \\
\hline & $\begin{array}{c}\text { Support } \\
\text { Infrastructure }\end{array}$ & & $\begin{array}{l}\text { Support, including } \\
\text { engineering tools and } \\
\text { IT systems }\end{array}$ & & Support systems & $\begin{array}{l}\text { Critical resources; } \\
\text { Trust building }\end{array}$ \\
\hline & Relationships & $\begin{array}{l}\text { Intra-firm dynamic } \\
\text { capability building }\end{array}$ & & $\begin{array}{c}\text { The role of key } \\
\text { network partners and } \\
\text { inter-firm } \\
\text { relationships }\end{array}$ & $\begin{array}{l}\text { Partnering modes; } \\
\text { firm and network } \\
\text { value sets }\end{array}$ & $\begin{array}{l}\text { Partner and process } \\
\text { selection (customers } \\
\text { and suppliers); } \\
\text { Developing longer } \\
\text { term relationships } \\
\text { (new and existing) }\end{array}$ \\
\hline & 'Product' & $\begin{array}{l}\text { Product lifecycle and } \\
\text { knowledge transfer }\end{array}$ & & $\begin{array}{l}\text { Product modularity; } \\
\text { SKU portfolio/profile }\end{array}$ & $\begin{array}{l}\text { Service offering; } \\
\text { outcomes/effects }\end{array}$ & $\begin{array}{c}\text { Consolidation of } \\
\text { concepts; Product } \\
\text { focus and definition }\end{array}$ \\
\hline
\end{tabular}

\section{Conclusions and suggestions for future research}

The focus of this research paper has been to better understand what role supply networks may play in the successful commercialisation of emerging technologies. One critical challenge is that there is no 
defined pathway for emerging firms to follow, with great uncertainty and risk inherent in final product definition and end-user requirements. In terms of supply network strategy, new actors and enterprises often fail to coordinate the external resource capabilities and core non-technical activities they may require, often focusing on managing internal capabilities. This is also reflected in the academic literature, with relatively limited research in this area of supply network design and management for early stage technology enterprises.

In addition to new entrants, this research also considers well established and mature organisations looking to capture value and diversify their product portfolios through the technology commercialisation route. To this effect, 'mature' organisations often need to radically 're-configure' their legacy supply networks, leveraging existing capabilities where possible, to support the emergence of a new technology and business model. While organisations may be classed as 'mature', it is argued that their supply networks never quite reach a stage of 'maturity'. Supply network emergence, evolution, transition and reconfiguration is a constant - due to ever-changing competitive priorities, emerging market opportunities and the dynamic nature of today's 'industrial enterprise'.

It is also argued that existing research on 'stages' for emerging industries are largely conceptual and descriptive, providing limited content and substance on what the supply network features of evolution may be. This can result in both subjective identification and classification and may not provide insights on optimal 'pathways' and 'operational actions' that firms need to consider. Hence, a generic 'stages' model to better understand supply network evolution - in the context of emerging technologies - was developed (underpinned by literature on industrial emergence and network theory) and then tested using a series of existing commercialisation case studies within PE. The aims of model development were two-fold, namely, to extend theoretical understanding of 'stages' and 'emergence' from a traditional technology and product perspective towards that of supply networks, and inform existing network analysis approaches previously used, to good effect, in mature contexts. Application and refinement of the stages model, using these case studies, has demonstrated that supply network emergence may be described as a hybrid process of forming new and restructuring existing legacy linkages.

At the practice level, the stages model may inform how best to manage critical network resources, and support the development and design of alternative business models and effective supply network strategies for transforming new technologies into marketable products. The approach has recently been adapted for a review of inkjet printing research and manufacturing in the pharmaceutical sector (Daly et al., 2015). In summary, the 'stages' model may serve as:

- An evaluation tool for emerging actors and enterprises to appraise their existing supply network competencies, their 'fit' with respect to business strategy, and overall interactions within an emerging industrial system

- A supply chain strategy demonstrator to inform effective supply network design for specific industrial emergence modes and new entrants

- A performance indicator of emerging industry development, as a whole, from a supply network perspective

- An network analysis approach with the potential of capturing emergent and mature contexts

There are a series of limitations to this study, which present interesting opportunities for future research. First, and inherent to the nature of emerging industries and sectors, was access to a significant number of case examples. While the stages model of supply network emergence was first developed using an extensive literature review, validation and insights were restricted to eight case studies (with supporting secondary data) across the PE sector. However, the selection criteria set out did allow a diversity of enterprises operating at different (and multiple) points across the value chain to be identified and targeted. These case organisations could be further segmented into clusters, allowing some insights into cross-cluster and within-cluster synergies and differences. In summary, 
additional validation with a more extensive set of cases would be beneficial. Secondly, this initial study was based on an industrial ecosystem map of the PE sector in 2011, where key institutional, industry sector specialists and supply network actors (at that time) had been captured. Access was limited to two SMEs and six OEMs at this juncture. This is understandable given sensitivities over IP and high rates of turnover/attrition, with respect to respondents and smaller firms. Hence, and as reflected in figure 2, the study may be biased towards the 'more mature' organisation case involving legacy supply networks and the leveraging of existing capabilities, where possible, to support the emergence of a new technology and business model.

However, one of the interesting aspects of engaging with industry is that it is possible to identify the practice need for new avenues of research (Childe, 2011). As part of project ReMediES (Reconfiguring Medicines End-2-End Supply), the PE industrial ecosystem map will be revisited in 2016 to chart industry evolution over this 5-year period, and to specifically assess emerging concepts and opportunities across the pharmaceutical value chain. Specific focus here centres on PE enabling alternative and novel routes to medicines production, and the delivery of added value to 'end-users' (patients and healthcare providers), in terms of e.g. improved product traceability and patient compliance. This activity is one of five application workstreams informing two advanced manufacturing supply chain platform projects - End-2-End (E2E) clinical trials (including both the physical and regulatory supply chain) and E2E commercial supply chains (from raw materials and production, right through to the patient). Product concepts in PE - linked to 'smart' packaging, 'intelligent' packs and flexible supply - are currently in development, supporting the design of E2E digital pharmaceutical supply chains (one of three flagship projects commissioned as part of commercial platform activities).

As discussed in section 6, future studies in the network configuration domain will look to validate the dimensions and sub-dimensions that are applicable for 'mature' industries and were used here in an emerging industry context. In order to capture configuration profiles associated with technology emergence and disruptive business models, this validation exercise will be used as a basis to further extend the network configuration approach to capture 'transitions' for both emerging and mature firms. Secondly, in order to achieve a sufficient level of granularity and discrimination, our research strategy will look to (i) target more 'nascent' and 'emergent' cases (for example, current studies involve developing supply networks for renewable feedstocks) and extend these analyses to other emerging industries in order to further test the stages model in a series of cross-sectoral studies (ii) explore if particular 'archetypes' or 'forms' of supply network may best support industrial system emergence and (iii) develop a generic set of performance measures for institutional stakeholders, that may be used to track emerging firm progress.

\section{Acknowledgements}

The authors would like to acknowledge support from the UK's EPSRC Centre for Innovative Manufacturing in Continuous Manufacturing and Crystallisation (CMAC), and the Advanced Manufacturing Supply Chain Initiative (AMSCI) project ReMediES (Reconfiguring Medicines End-2End Supply).

\section{References}

Adner, R, Levinthal, D. A. (2002) 'The emergence of emerging technologies'. INSEAD working paper series [online] at: http://www.insead.edu/facultyresearch/research/doc.cfm?did=47742. Accessed 26.01.15

Adner, R., Kapoor, R. (2010) 'Value creation in innovation ecosystems: how the structure of technological interdependence affects firm performance in new technology generations', Strategic Management Journal, Vol. 33, pp. 306-333. 
Adomavicius, G., Bockstedt, J.C., Gupta, A., Kauffman, R.J. (2007) 'Technology roles and paths of influence in an ecosystem model of technology evolution', Inf. Technol. Management, Vol. 8, pp. 185-202.

Aldrich, H.E., Fiol, C.M. (1994) 'Fools Rush In? The Institutional Context of Industry Creation'. Academy of Management Review, Vol.19, No.4, pp. 645-670.

Anderson, P., Tushman, M.L. (1990) 'Technological Discontinuities and Dominant Designs: A Cyclical Model of Technological Change', Administrative Science Quarterly, Vol. 35, No. 4, pp. 604-633.

Benbasat, I. (1984) 'An Analysis of Research Methodologies', in, The Information Systems Research Challenge, F. Warren McFarlan (ed.), Harvard Business School Press, Boston, Massachusetts, pp. 47-85.

Blois J.K. (1996) 'Vertical quasi-integration', in, Firms, Organizations and Contracts: A Reader in Industrial Organization. Buckley P.J., Michie, J. (eds.). Oxford University Press: New York, pp. 320-338.

Brown, SL., Eisenhardt, K.M. (1995) 'Product Development: Past Research, Present Findings, and Future Directions', The Academy of Management Review, Vol. 20, No.2, pp. 343-378

Calori, R. (1985) 'Effective Strategies in Emerging Industries', Long Range Planning, Vol. 18, No.3, pp. 55-61.

Casson M. (1998) Information and Organization: A New Perspective on the Theory of the Firm. Oxford University Press: New York.

Childe, S.J. (2011) 'Case studies in operations management', Production Planning and Control, 22, 2, 107.

Christensen, C.M. (2003) 'Beyond The Innovator's Dilemma', Strategy \& Innovation, Vol. 1, No. 1, March/April

Christopher, M., Towill, D.R. (2002) ‘Developing Market Specific Supply Chain Strategies', International Journal of Logistics Management, Vol. 13 Iss: 1, pp.1-14.

Churchill, N. and Lewis, V. (1983) 'The five stages of small business growth'. Harvard Business Review, May-June, pp. 30-50.

Churchill N., (1997) The Six Key Phases of Company Growth. In Birley, S. and Muzyka, D. (Eds), Mastering Enterprise, London: Financial Times, Pitman, pp. 213- 219.

Cooper, R.G. (1993) Winning at New Products: Accelerating the Process from Idea to Launch, Addison-Wesley, Reading, MA.

Cooper, R.G. (1994) 'New Products: The Factors that Drive Success', International Marketing Review, Vol. 11, Iss: 1, pp. 60-76.

Cusumano, M., Mylonadis, Y., Rosenbloom, R. (1992) 'Strategic maneuvering and mass market dynamics: the triumph of VHS over Beta. Business History Review, Vol. 66, No. 1, pp. 51-94.

Daly, R., Harrington, T.S., Martin, G.D., Hutchings, I.M. (2015) 'Inkjet printing for pharmaceutics - A review of research and manufacturing', International Journal of Pharmaceutics. Vol. 494, No. 2, pp. 554-567. DOI: 10.1016/j.ijpharm.2015.03.017 
Den Hartigh, E., Asseldonk, T. V. (2004). 'Business ecosystems: A research framework for investigating the relation between network structure, firm strategy, and the pattern of innovation diffusion', European Chaos and Complexity in Organisations Network (ECCON), Conference proceedings, pp. 1-38. Available at: http://www.chaosforum.com/docs/nieuws/Ecosystems.pdf (accessed 10.03.2015).

Den Hartigh, E., Ortt, J.R., Van de Kaa, G., Stolwijk, C. (2010) 'Technology Standards Battles and Business Networks During the Technology Life Cycle: A Comparative Case Study, International Conference on Management of Technology proceedings, 8-11th March, Cairo Egypt.

Dodgson, M. (2000) The Management of Technological Innovation: An International and Strategic Approach, Oxford Press, Oxford UK.

Dyer J.H., Singh, H. (1998) 'The relational view: cooperative strategy and sources of interorganizational competitive advantage', Academy of Management Review, Vol. 23, pp. 660-679.

Edquist, C., Johnson, B. (1997) 'Institutions and organizations in systems of innovation'. In, C. Edquist (Ed.), Systems of Innovation: Technologies, Institutions and Organizations, Pinter, London

Eisenhardt, K. M. (1989) 'Building Theories from Case Study Research'. Academy of Management Review, 14, 532-550.

Eisenhardt, K. M., Graebner, M. E. (2007) 'Theory building from cases: Opportunities and challenges', Academy of Management Journal, 50, 25-32.

Fisher, ML., (1997), What is the Right Supply Chain for Your Product? Harvard Business Review. March-April. Available at: https://hbr.org/1997/03/what-is-the-right-supply-chain-for-your-product (accessed 12.04.15).

Fligstein, N. (2001) The Architecture of Markets: An Economic Sociology of Twenty-First-Century Capitalist Societies. Princeton University Press, Princeton, NJ.

Greiner, L.E. (1972) ‘Evolution and Revolution as Organizations Grow’, Harvard Business Review, pp. 37-46, July-August

Gulati, R. (1995a). 'Does familiarity breed trust? The implications of repeated ties for contractual choice in alliances', Academy of Management Journal, Vol. 38, pp. 85-112.

Gulati, R. (1995b) 'Social Structure and Alliance Formation Patterns: A Longitudinal Analysis'. Administrative Science Quarterly, Vol. 40, No. 4, pp. 619-652.

Hadjadj, H.N (2013) "Exploring approaches to supply networks transformation mapping - A case study on the strategic implications of composites in the civil aircraft industry", M.Phil dissertation in Industrial Systems, Manufacture and Management, University of Cambridge

Hansen, M.T., Birkinshaw J. (2007) The innovation value chain, Harvard Business Review. Vol. 85, No. 6, pp. 121-130.

Harrington, T.S., Srai, J.S. (2012) 'Defining product-service network configurations and location roles: a current and future state analysis framework for international engineering operations', International Journal of Product Development, Vol. 17, Nos. 3/4, pp. 228-253.

Harrington, T.S., Kirkwood, D.A., Srai, J.S. (2012) 'Performance metric selection methodology for multi-organizational service network integration', Journal of Applied Management and Entrepreneurship, Vol. 17, No. 3, pp. 20-35 
Harrington, T.S. Srai, J.S., Christodoulou, P. (2015) 'Connecting the unconnected: new thinking on next generation supply chains', IfM Review, Issue 4, University of Cambridge, pp. 24-26. Available at: http://www.ifm.eng.cam.ac.uk/research/ifm-review/issue-4/ (accessed 12.3.2016)

Harrington, T.S., Srai, J.S., Kumar, M., Wohlrab, J. (2016a) 'Identifying design criteria for urban system 'last-mile' solutions - a multi-stakeholder perspective', Production Planning and Control, Vol. 27, No. 6, pp. 456-476. DOI:10.1080/09537287.2016.1147099

Harrington, T.S., Srai, J.S. (2016b) 'Designing a 'concept of operations' architecture for next generation multi-organisational service networks', Al \& Society: Journal of Knowledge, Culture and Communication (in press)

Helfat, C.E. (1997) 'Know-how and asset complementarily and dynamic capability accumulation: The case of R\&D', Strategic Management Journal, Vol. 18, No. 5, pp. 339-360.

Hill, C.W.L. (1997) 'Establishing a Standard: Competitive Strategy and Technological Standards in Winner-Take-All Industries', Academy of Management Executive, Vol. 11, No. 2, pp. 7-25.

Hills, S.B., Sarin, S. (2003) 'From Market-Driven to Market-Driving: A New Paradigm for the Marketing of High-Tech Products and Innovations', Journal of Marketing Theory and Practice, Vol. 11, No.3, pp. 13-24.

Holloway, S. S., Sebastiao, H. J. (2010). The Role of Business Model Innovation in the Emergence of Markets: A Missing Dimension of Entrepreneurial Strategy? Journal of Strategic Innovation and Sustainability, 6(4), 86-101.

Jaworski, B., Kohli, A.K., Sahay, A. (2000) 'Market-Driven Versus Driving Markets', Journal of the Academy of Marketing Science, Vol. 28, No. 1, pp. 45-54.

Jacobsson, S., Johnson, A., (2000) 'The diffusion of renewable energy technology: an analytical framework and key issues for research'. Energy Policy, Vol. 28, No. 9, 625-640.

Kamath, R.R., Liker, J.K. (1994) 'A second look at Japanese product development', Harvard Business Review, November. Available at https://hbr.org/1994/11/a-second-look-at-japanese-productdevelopment. Accessed 14.04.015)

Kay N.M. (1997) Patterns in Corporate Evolution, Oxford University Press, New York

Kazanjian, R. K. (1988) 'Relation of dominant problems to stages of growth in technology- based new ventures'. Academy of Management Journal, Vol. 31, pp. 257-279.

Kazanjian, R. K., Drazin, R. (1989) 'An empirical test of a stage of growth progression model'. Management Science, Vol. 35, No. 12, pp. 1489-1503.

Kazanjian, R. K., Drazin, R. (1990) 'A stage-contingent model of design and growth for technology based new ventures', Journal of Business Venturing Vol. 5, Iss. 3, pp. 137-150.

Kirkwood, D.A., Harrington, T.S., Srai, J.S.S. (2009) Emergent supply networks - How supply network creation can help shape industrial emergence, CIM briefing No. 5, University of Cambridge, Institute for Manufacturing. ISSN 1755-9898.

Kumar, N., Scheer, L., Kotler, P. (2000) 'From Market Driven to Market Driving', European Management Journal, Vol. 18, No. 2, pp. 129-142.

Lee, HL. (2002) 'Aligning Supply Chain Strategies with Product Uncertainties', California Management Review, Vol. 44, No. 3, pp. 105-119. 
Lepak, D. P., Smith, K. E. N. G., Taylor, M. S. (2007) 'Value creation and value capture: a multilevel perspective', Academy of Management Review, Vol. 32, No.1, pp. 180-194.

Leibold, M., Probst, G., Gibbert, M. (2002) Strategic Management in the Knowledge Economy: New Approaches and Business Applications. Wiley, New York.

Levitt, T. (1965) 'Exploit the product life cycle', Harvard Business Review, November. Available at: https://hbr.org/1965/11/exploit-the-product-life-cycle (accessed 10.03.15)

Mankins, J. (1995) Technology Readiness Levels. NASA White paper. Available at: http://www.hq.nasa.gov/office/codeq/trl/trl.pdf (accessed 10.03.15)

Meredith, J. (1998) 'Building operations management theory through case and field research', Journal of Operations Management, 16(4), pp.441-454.

Moore, J. F. (1993) 'Predators and prey: The new ecology of competition', Harvard Business Review Vol. 71, No. 3, pp. 75-83.

NAE (2008) The offshoring of Engineering: Facts, Unknowns, and Potential Implications, National Academy of Engineering, National Academies Press, Washington, DC.

Nair, A., Boulton, W.R., (2008) 'Innovation-oriented operations strategy typology and stage-based model', International Journal of Operations and Production Management, Vol. 28, No. 8, pp. 748771.

Nishiguchi, T. (1994). Strategic Industrial Sourcing: The Japanese Advantage. Oxford University Press, Oxford UK.

Ortt, J.R., Schoormans, J.P.L. (2004) 'The pattern of development and diffusion of breakthrough communication technologies', European Journal of Innovation Management, Vol. 7, Iss. 4, pp. $292-302$.

Ortt J.R., Egyedi, T.M. (2014) 'The Effect of Pre-Existing Standards and Regulations on the Development and Diffusion of Radically New Innovations'. International Journal of IT Standards and Standardization Research, Vol. 12, Iss. 1, pp.17-37

Power, D.J., Sohal, A.S., Rahman, S.U. (2001) 'Critical success factors in agile supply chain management - An empirical study', International Journal of Physical Distribution and Logistics Management, Vol. 31, Iss: 4, pp. 247-265.

Phaal, R., O'Sullivan, E., Farrukh, C., Probert, D. (2009) 'Developing a framework for mapping industrial emergence', PICMET: Portland International Center for Management of Engineering and Technology, Conference proceedings, pp. 428-440.

Ragatz, G.L., Handfield, R.B., Scannell, T.V. (1997) 'Success factors for integrating suppliers into new product development', Journal of Product Innovation Management, Vol. 14, pp. 190-202.

Rogers, E. M. (2003) Diffusion of Innovations, 5th edition, The Free Press.

Royal Academy of Engineering (2012), 'Industrial Systems: capturing value through manufacturing', ISBN 1-903496-69-1

Remenyi, D., Williams, B., Money, A. \& Swartz, E. (2003) Doing research in business and management: An introduction to process and method, London, SAGE Publications. 
Santos F.M., Eisenhardt K.M. (2009) 'Constructing Markets and Shaping Boundaries: Entrepreneurial Power in Nascent Fields', The Academy of Management Journal, Vol. 52, No. 4, pp. 643-671.

Shapiro, C., Varian, H.R. (1999) 'The Art of Standards Wars', California Management Review, 41(2) pp. 8-32.

Sarasvathy, S.D. (2001) 'Causation and Effectuation: Toward a Theoretical Shift from Economic Inevitability to Entrepreneurial Contingency', Academy of Management Review, Vol. 26, No. 2, pp. 243-263.

Sarasvathy, S.D., Dew, N. (2005) 'New Market Creation through Transformation', Journal of Evolutionary Economics, Vol.15, pp. 533-565.

Schneemann, M.W., (2013) "Exploring approaches to supply networks transformation mapping - A case study on the strategic implications of e-mobility for the German auto industry", M.Phil dissertation in Industrial Systems, Manufacture and Management, University of Cambridge

Sebastiao, H., Golicic, S. (2008) 'Supply chain strategy for nascent firms in emerging technology markets', Journal of Business Logistics, Vol. 29, No. 1, pp. 75-92.

Shiba, T. (1997) 'A path to the corporate group in Japan: Mitsubishi heavy industries and its group formation', in, Beyond the Firm: Business Groups in Historical Perspective, Shiba T, Shimotani M (eds.). Oxford University Press, New York, pp. 167-184.

Simchi-Levi, D. Fine, C.H. (2010) 'Your next supply chain', MIT Sloan Management Review, Vol. 51, No. 2, pp. 17- 25.

Smitka, M.J. (1991) Competitive Ties: Subcontracting in the Japanese Automotive Industry. Columbia University Press, New York.

Srai, J.S. and Gregory, M. (2008) 'A Supply Network Configuration Perspective on International Supply Chain Development', International Journal of Operations and Production Management, Vol. 28, No. 5, pp. 386-411.

Srai J.S. (2010) 'A preliminary map of the UK Industrial Biotechnology Supply Chain', University of Cambridge, IfM Publication. ISBN: 978-1-902546-42-1.

Srai, J.S., Christodoulou, P., Harrington, T.S., (2014) 'Configuring global value networks within industrial ecosystems', in 'Capturing value from global networks: gaining global competitive advantage through configuring production, supply and service networks', University of Cambridge, editors. J.S. Srai and P. Christodoulou, pp. 38-51.

Srai, J.S., Badman, C., Krumme, M., Futran, M., Johnston, C. (2015a), "Future supply chains enabled by continuous processing - opportunities and challenges. May 20-21, 2014 Continuous Manufacturing Symposium", Journal of Pharmaceutical Sciences, Article first published online: 28th January 2015. DOI: 10.1002/jps.24343

Srai, J.S., Harrington, T.S., Alinaghian, L.A., Phillips, M.A. (2015b),'Evaluating the potential for the continuous processing of pharmaceutical products - a supply network perspective', Chem. Eng. Process., Vol. 97, pp. 248-258.

Suárez, F.F. (2004) 'Battles for technological dominance: an integrative framework', Research Policy Vol. 33, pp. 271-286.

Tao, L., Probert, D., Phaal, R. (2010) 'Towards an integrated framework for managing the process of 
innovation', R\&D Management, Vol. 40, pp.19-30.

Theyel, G., Taylor, G., Heffernan, P. (2011) 'Bridging the Gaps in Industry Evolution: Solar Photovoltaic Industry', IEEE International Technology Management Conference Proceedings, pp.1048-1052

Thomke, S. (2003) Experimentation Matters: Unlocking the Potential of New Technologies for Innovation. Harvard Business School Press, Boston, MA.

Tushman, M.L., Rosenkopf, L. (1992) 'Organizational determinants of technological change. Towards a sociology of technological evolution', Research in Organization Behavior, Vol. 14, pp. 311-347.

Utterback, J.M., Abernathy, W.J. (1975) 'A dynamic model of process and product innovation', Omega, Vol. 3, Iss. 6, pp. 639-656.

Utterback, J.M., Suárez F.F. (1993) 'Innovation, competition, and industry structure', Research Policy, Vol. 22, Iss. 1, pp. 1-21.

Voelpel, S.C., Leibold, M., Tekie, E.B (2004) 'The Wheel of Business Model Reinvention: How to Reshape Your Business Model to Leapfrog Competitors', Journal of Change Management, Vol. 4, No. 3, pp. 259-276.

Voss, C., Tsikriktis, N. and Frohlich, M. (2002) "Case research in operations management", International Journal of Operations \& Production Management, 22(2): 195-219.

Voss, C. (2009) 'Case Research in Operations Management', in Karlsson, C. (Ed.), Researching Operations Management, Routledge, New York, pp. 162-196.

Williamson, O.E. (1985) The Economic Institutions of Capitalism: Firms, Markets, Relational Contracting. Free Press, New York.

Womack J.P., Jones D.T., Roos, D. (1990) The Machine that Changed the World. HarperCollins, New York.

Zahra, S.A., Nielsen, A.P. (2002) 'Sources of capabilities, integration and technology commercialization', Strategic Management Journal, Vol. 23, No. 5, pp. 377-398.

Zhang, Y., Gregory, M. and Shi, Y. (2007) 'Global Engineering Networks (GEN): The Integrating Framework and Key Patterns', Proceedings of the Institution of Mechanical Engineers, Part B: Journal of Engineering Manufacture, Vol. 221, pp.1269-1283.

Zhang, Y. and Gregory, M. (2011) 'Managing Global Network Operations along the Engineering Value Chain', International Journal of Operations \& Production Management, Vol. 31, No. 7, pp.736764. 